\title{
The PCAOB Audit Quality Indicator Framework Project: Feedback From Stakeholders
}

\author{
Arianna S. Pinello, Florida Gulf Coast University, USA \\ Ara G. Volkan Florida Gulf Coast University, USA \\ Justin Franklin, Gartner, Inc., USA \\ Michael Levatino, Myers, Brettholtz \& Co., USA \\ Kimberlee Tiernan, Guest Services, Inc., USA
}

\begin{abstract}
Audit Quality Indicators (AQIs), as defined by the Center for Audit Quality, include four different elements: firm leadership and tone at the top; engagement team knowledge, experience, and workload; monitoring; and auditor reporting. AQIs are quantitative and qualitative measures designed to improve audit quality and help audit committees select the best audit firm for their current needs. They are intended to increase the reliability and accuracy of financial reporting. The Public Company Accounting Oversight Board (PCAOB) has issued a concept release proposing twenty-eight potential AQIs for use in the United States. The PCAOB release describes the AQI reporting framework and asks for public opinion on whether or not it should be implemented. This study reviews the comment letters in response to PCAOB Docket 041, Concept Release on Audit Quality Indicators, and the AQI reporting frameworks currently in place in the United Kingdom, Singapore, and other countries. After reviewing the PCAOB's proposed AQI framework, response letters to Docket 041, and the AQI frameworks used in other countries, this paper provides an opinion on how the PCAOB should proceed with the AQI framework initiative in the U.S. The analysis suggests that AQI reporting should not be mandated in the U.S., but should become a flexible and voluntary framework that provides valuable information, enhances transparency in the audit profession, and establishes a commitment to the improvement of audit quality.
\end{abstract}

Keywords: AQIs; PCAOB; Audit Transparency; Audit Quality; Quality Disclosures

\section{INTRODUCTION}

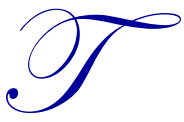

o increase the transparency of the independent audit, a proposal has been released to define and improve audit quality (AQ). The initiative (PCAOB, 2015) addresses the following questions: 1) what factors contribute to a quality audit and how could they be measured; 2) what is the basis for comparison of different audits and different firms; and 3) how can firms commit to improving AQ given a consensus on how to define and measure AQ.

According to the Government Accountability Office (GAO), AQ may be defined as:

"a quality audit is one in which the audit is conducted in accordance with generally accepted auditing standards (GAAS) to provide reasonable assurance that the audited financial statements and related disclosures are (1) presented in accordance with generally accepted accounting principles (GAAP) and (2) are not materially misstated, whether due to errors or fraud" (Smith, Bedard, and Johnstone, 2009).

A quality audit allows an auditor to discover a material misstatement or identify a breakdown in internal control. DeFond and Zhang (2014) add that high AQ assures that the firm's financial condition is faithfully represented, given its accounting system and other characteristics. Other determinants of AQ are the audit team, task characteristics, and the environment (Gaynor, Kelton, Mercer, and Yohn, 2016). 
While many audit firms have internally measured AQ for decades, there has been a recent emphasis by regulators and other oversight bodies to construct reporting frameworks that define and measure AQ for all audit firms in a given country. Worldwide, nine organizations independently developed frameworks for reporting audit quality indicators (AQIs). These organizations range from those in the United States and Canada to those in Europe and Asia. Given these individual initiatives, there is no universally accepted method for measuring AQ and the frameworks that have been proposed and/or implemented have significant differences. Some organizations have taken a principles-based approach, while others have mandated rules for AQIs (Center for Audit Quality, 2014). Some initiatives propose reporting ten AQIs while others list up to 28 indicators. Globally, no organization can agree whether the information should be private or public. There are also discussions on whether AQIs should be qualitative, quantitative, or a mixture of both. Due to the significant differences between various initiatives, the Federation of European Accountants (FEA) suggested that organizations worldwide work together to create a set of AQIs and put forward twelve indicators (Exhibit 1) as a starting point (FEA, 2015).

Exhibit 1. Twelve AQIs Proposed by the FEA

I. Availability

1. Staffing Leverage

2. Partner Workload

3. Manager and Staff Workload

4. Technical Accounting and Auditing Resources

5. Persons With Specialized Skills and Knowledge

\section{Competence}

6. Experience of Audit Personnel

7. Industry Expertise of Audit Personnel

8. Turnover of Audit Personnel

9. Amount of Audit Work Centralized at Service Centers

10. Training Hours per Audit Professional

III. Focus

11. Audit Hours and Risk Areas

12. Allocation of Audit Hours to Phases of the Audit

Source: Federation of European Accountants (2015).

\section{PURPOSE}

There is diversity in AQI recognition, measurement, and reporting practices worldwide. Thus, it is warranted to review the comment letters in response to PCAOB Docket 041, Concept Release on Audit Quality Indicators, and the voluntary AQI reporting frameworks currently in place in the United Kingom, Singapore, and other countries and make recommendations concerning how the PCAOB should proceed with the AQI framework initiative in the U.S.

\section{LITERATURE REVIEW}

In October 2008, the Advisory Committee on the Auditing Profession released a report that called for building a sustainable audit profession and promoting transparency and trust in the financial statements. The report contained many recommendations to improve the transparency of financial statements and audit reports and focused on the ability of users to observe AQ. The report provided a recommendation to the PCAOB to develop key AQIs and require the audit firms to disclose them (Berdard, Johnstone, and Smith, 2010).

The concept of reporting AQIs in the United States has support among governmental agencies, public accounting firms, and other stakeholders who would potentially be affected by this initiative. These stakeholders argue that AQIs lead to audit transparency, which, in turn, enhances AQ. Thus, high quality audit firms are rewarded, while low quality firms have incentive to improve and repair their standing (Bedard et al., 2010). The main reason that the US does not have an AQ reporting framework in place is that measuring AQ is not easy and there are several potential unintended consequences. An example of an unintended consequence is that firms may place too much emphasis on achieving high AQ rankings rather than actually improving AQ (Bedard et al. 2010). 
It is extremely difficult to put a measure on AQ. Users, auditors, regulators, and society advocate different sets of AQIs to measure audit quality (Knechel, Krishnan, Pevzner, Shefchik, and Velury, 2013). Creating a framework to measure AQ is an even more difficult task. Knechel et al. (2013) propose a balanced scorecard approach to define AQIs by dividing AQ into four categories: inputs, processes, outcomes, and context. Their approach also includes reporting financial and non-financial measures.

Audit firms, audit committee members, investors, governmental agencies, and financial statement preparers held a symposium in 2012 to discuss AQIs and their potential integration as a mandatory reporting item in the U.S. financial reports. Two main concerns were: 1) how to measure audit effectiveness to determine AQ; and 2) how to use AQIs to measurably enhance quality (Martin, 2013). While no time was spent at this symposium to discuss the specifics of AQIs and how they would be reported or measured, a great deal of time was spent discussing the value of AQIs and the potential demand within the audit industry.

The Center for Audit Quality (CAQ) has a strong involvement in the AQI initiative. In early 2015, CAQ members, which consist of 30 corporations and 10 accounting firms, had a pilot testing of AQIs. CAQ CEO Cindy Fornelli stated that the exercise both validated the CAQ's approach to AQ measurement and revealed areas where improvements are needed (Fornelli, 2016). The CAQ held roundtables in London, New York, Singapore, and Chicago to discuss the AQI project. The discussions led to dividing AQIs into four broad categories: 1) firm leadership and tone at the top; 2) indicators of engagement, such as team knowledge, experience, and workload; 3) monitoring, such as looking at internal quality review findings and trends in PCAOB inspection results; and 4) indicators associated with auditor reporting (Jeffrey, 2016). Audit committee members and audit engagement teams that were present at the roundtable discussions provided valuable feedback and were generally supportive of the proposed AQI framework. Audit committees preferred a flexible approach with the ability to tailor AQIs to the needs of their firm. They also felt that requiring the disclosure of engagement-level AQIs will result in unintended consequences and that disclosures of AQIs should be voluntary (Tysiac, 2016).

\section{LETTERS IN RESPONSE TO CONCEPT RELEASE ON AUDIT QUALITY INDICATORS}

In 2015, the PCAOB released concept 2015-005, Concept Release on Audit Quality Indicators, in which it encouraged feedback from the various stakeholders that would be affected by this mandate. The release provided a list of 28 indicators in the three categories delineated in Exhibit 2 (Rezaee et al., 2016). The PCAOB gave individuals and companies an opportunity to provide feedback from July 1, 2015 through September 29, 2015. 
Exhibit 2. Twenty-eight AQIs Proposed by the U.S. PCAOB

\begin{tabular}{|c|c|c|}
\hline \multirow{3}{*}{ 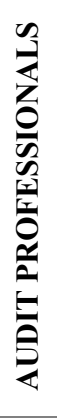 } & Availability & $\begin{array}{ll}\text { 1. } & \text { Staffing Leverage } \\
\text { 2. } & \text { Partner Workload } \\
\text { 3. } & \text { Manager and Staff Workload } \\
\text { 4. } & \text { Technical Accounting and Auditing Resources } \\
\text { 5. } & \text { Persons with Specialized Skill and Knowledge }\end{array}$ \\
\hline & Competence & $\begin{array}{ll}\text { 6. } & \text { Experience of Audit Personnel } \\
\text { 7. } & \text { Industry Expertise of Audit Personnel } \\
\text { 8. } & \text { Turnover of Audit Personnel } \\
\text { 9. } & \text { Amount of Audit Work Centralized at Service Centers } \\
\text { 10. } & \text { Training Hours per Audit Professional }\end{array}$ \\
\hline & Focus & $\begin{array}{l}\text { 11. Audit Hours and Risk Areas } \\
\text { 12. Allocation of Audit Hours to Phases of the Audit }\end{array}$ \\
\hline \multirow{11}{*}{ 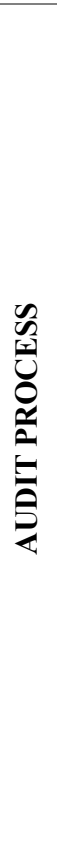 } & Tone at the Top and Leadership & 13. Results of Independent Survey of Firm Personnel \\
\hline & Incentives & $\begin{array}{l}\text { 14. Quality Ratings and Compensation } \\
\text { 15. Audit Fees, Effort, and Client Risk }\end{array}$ \\
\hline & Independence & 16. Compliance with Independence Requirements \\
\hline & Infrastructure & 17. Investment in Infrastructure Supporting Quality Auditing \\
\hline & Monitoring and Remediation & $\begin{array}{l}\text { 18. Audit Firms' Internal Quality Review Results } \\
\text { 19. PCAOB Inspection Results } \\
\text { 20. Technical Competency Testing }\end{array}$ \\
\hline & Financial Statements & $\begin{array}{l}\text { 21. Frequency and Impact of Financial Statement } \\
\text { Restatements for Errors } \\
\text { 22. Fraud and other Financial Reporting Misconduct } \\
\text { 23. Inferring Audit Quality from Measures of Financial } \\
\text { Reporting Quality }\end{array}$ \\
\hline & Financial Statements & $\begin{array}{l}\text { 24. Frequency and Impact of Financial Statement } \\
\text { 25. Restatements for Errors } \\
\text { 26. 22. Fraud and other Financial Reporting Misconduct } \\
\text { 27. 23. Inferring Audit Quality from Measures of Financial } \\
\text { 28. Reporting Quality }\end{array}$ \\
\hline & Internal Control & 29. Timely Reporting of Internal Control Weaknesses \\
\hline & Going Concern & 30. Timely Reporting of Going Concern Issues \\
\hline & $\begin{array}{l}\text { Communications between } \\
\text { Auditors and Audit Committee }\end{array}$ & $\begin{array}{l}\text { 31. Results of Independent Surveys of Audit Committee } \\
\text { Members }\end{array}$ \\
\hline & Enforcement and Litigation & $\begin{array}{l}\text { 32. Trends in PCAOB and SEC Enforcement Proceedings } \\
\text { 33. Trends in Private Litigation }\end{array}$ \\
\hline
\end{tabular}

Source: PCAOB Release No. 2015-005, page 13

The analysis of the 48 comment letters showed that 31\% (15 letters) supported the concept release, $44 \%$ ( 21 letters) supported it subject to certain revisions, and 25\% (12 letters) opposed it (comment letters are available at: https://pcaobus.org/Rulemaking/Pages/Docket041Comments.aspx). The characteristics of those providing feedback are summarized in Exhibit 3. Categorizing a letter as in support of (S) or against (A) the concept release was straightforward. The conditional support (CS) category was assigned when the respondent was generally supportive of the concept release but asked for certain revisions in the proposed framework.

Exhibit 3. Respondent Characteristics

\begin{tabular}{l|c|c|c}
\hline \multicolumn{1}{|c|}{ Respondent } & S & CS & A \\
\hline CPA Firms and Individual CPAs & 4 & 6 & 3 \\
\hline Professional CPA/CMA Organizations & 2 & 6 & 3 \\
\hline Investor Organizations and Individual Investors & 5 & 1 & 13 \\
\hline Other Professional Organizations & 1 & 4 & 2 \\
\hline Audit Committee representatives & 1 & 1 & 0 \\
\hline Standard Setting Bodies & 1 & 2 & 3 \\
\hline Academicians & 1 & 1 & 0 \\
\hline TOTALS & 15 & 21 & \\
\hline
\end{tabular}


The CPA firms and individual CPAs constituted the largest category of respondents (13/48), followed by CPA/CMA organizations (11/48). Individual investors and investor organizations (8/48), other professional organizations (5/48), and audit committees (5/48) were also represented. Finally, academicians (3/48) and standard setting bodies (3/48) provided the remaining responses.

There were many common reasons why respondents (three CPA firms and organizations, three professional organizations, three audit committee representatives, two investor organizations, and one academician) were against the proposed AQI reporting framework. First, it would be unfair to compare larger CPA firms to smaller ones. The framework can create an unnecessary burden on the smaller CPA firms because they have fewer resources and can appear less efficient at providing quality audits. Ross Fuerman, a professor from Suffolk University, believes that this concept release will lessen the appeal of hiring a smaller audit firm. Proposed AQ indicators could be crude and potentially misleading because smaller firms have significantly different clientele than the larger accounting firms (Fuerman, 2015). Next, the Council of Institutional Investors was against the concept release because AQIs would not provide any direct value to investors (Mahoney, 2015). This view may not be accurate because improving AQ directly affects investors by providing a scale to judge the effectiveness and thoroughness of the audit firms, leading to increased investor confidence in the auditing profession and in the process of selecting auditors.

Another common argument against the concept release was that AQI information should remain confidential and should not be made public. For example, Belden, Inc. stated that they do not believe it is necessary or valuable to publicly disclose data on AQIs or on the evaluation of AQIs by audit committees (Minnich, 2015). Such arguments indicate that the PCAOB should determine which data should be a required disclosure and what should be voluntary.

Many of the CPA firms, individual CPAs, and CPA organizations wrote response letters that were conditionally supportive (twelve out of 21 conditional support letters). Other professional organizations and standard setters constituted the next group of conditional responses (six out of 21 conditional support letters). The remaining three out of 21 letters were evenly divided among the academicians, audit committee representatives, and investors.

Conditional support letters generally supported the AQI project but felt that further research and revisions would be needed to make a significant impact. The major reason for CS was the observation that the proposed number of AQIs was too large (17/21 CS letters). For example, the Institute of Management Accountants (2015) felt that the proposal was an important initiative but 28 AQI's were too many and further felt that it would lead to unnecessary complexity.

Another major reason was the suggestion that only audit committees should receive the AQI information (13/21 CS letters). For example, McGladrey, LLP (2015) stated that some of the engagement-level and firm-level AQIs discussed in the PCAOB's concept release could be helpful to audit committees, but only if adequate context is provided through a discussion with the auditor. We agree with this suggestion because without context, most of the AQIs could be misleading and misrepresent the position of the audit firm.

Thus, the majority of the comments in the conditional support category stated that the concept release was a good start but needed improvements. Several responses also recommended that the reporting of AQIs should not be mandatory, rather, they should be used as a tool for evaluating firms on a case-by-case basis. These respondents believed that the voluntary reporting of AQIs would be the most beneficial and maximize their effectiveness. For example, KPMG, LLP (2015) commented as follows:

"We believe that communication of AQIs should be voluntary, rather than mandatory, and driven, primarily, by the needs and interests of the audit committee (although the auditor is always free to communicate information that the auditor believes is relevant). A voluntary non-prescriptive approach provides both the auditor and the audit committee the flexibility necessary to focus on the relevant information that affects the quality of a particular audit."

The analysis of the letters showed that while the majority of individuals and organizations that sent comment letters supported or conditionally supported the concept release (36/48), audit committee representatives were generally against it ( $3 / 5$ letters filed). In addition, seven of the 48 responses were filed by foreign organizations that either supported (four out of seven) or conditionally supported the concept release (three out of seven). The analysis of their letters indicates that they believed the proposed framework would bring a new level of transparency into the United States, one that has been present in other countries over the last decade. Most of the foreign organizations believed 
that a phased-in approach would be necessary to make the proposal work. The International Federation of Accountants supported the proposal because the phased-in approach is more likely to enable a feedback loop that could inform the optimization of the concept, ensure consistency of implementation, and allow for risks and issues to be addressed (Choudhury, 2015).

In summary, AQIs should be used to drive the conversation and ensure that the proper conversations are actually occurring. If the proposed AQI framework were required, it would limit the ability of firms to customize the information from each engagement and would restrict the effectiveness of the AQIs. While the concept release is a step in the right direction to improving transparency in financial reporting, most parties can agree that improvements need to be made before implementation begins. The framework will instill greater confidence in the audit industry and lead to greater confidence in the U.S. capital markets.

\section{REPORTING OF AQIS IN OTHER COUNTRIES}

Internationally, there has been an increasing emphasis by regulators, investors, and audit firms to develop a framework that defines and measures AQ. Despite the global effort, AQI initiatives are extremely diverse, and a uniform framework is nowhere in sight. As the push to measure and define audit quality intensified, numerous developments have led to initiatives and proposals being issued worldwide. The United Kingdom's Financial Reporting Council (FRC), the Netherland's Institute of Chartered Accountants, the Canadian Public Accountability Board, the Chartered Accountants of Australia and New Zealand, the Accounting and Corporate Regulatory Authority of Singapore, and the Federal Audit Oversight Authority in Switzerland have all led the way in AQI initiatives.

The FRC began discussing the importance of defining AQ in its 2006 report, Promoting Audit Quality, and approached the issue by identifying the key elements that separate a high quality audit from a low quality audit. According to the FRC, the five main drivers of AQ are firm culture, skill of audit personnel, audit effectiveness, the usefulness and reliability of audit reporting, and factors that auditors cannot control. The FRC also identified the importance of, and possible threats to, each driver of audit quality (FRC, 2006). In February 2008, the FRC released its AQI framework to complement the existing guidelines and regulations. The framework was created in order to enhance the dialogue between auditors, audit committees, financial statement preparers, and investors regarding audit quality. Its intent is to help companies evaluate audit proposals, aid audit committees in assessing the effectiveness of an audit, increase transparency for stakeholders, help ensure high quality audits are being performed, and help regulators monitor the audit profession (FRC, 2008).

Following the release of the framework by the FRC, the Policy and Reputation Group of the FRC identified key factors that contribute to audit quality. Such key factors are measureable and can be disclosed in one of four categories: 1) external investigations; 2) AQ monitoring; 3) funds dedicated to software and staff; and 4) internal and external survey results (FRC, 2015). Six of the largest firms in the United Kingdom voluntarily agreed to report these factors and disclose the qualitative and quantitative information in their annual transparency reports. The initiative has had great success and, according to the FRC, audit reports better describe the audit processes used to achieve high quality audits. (FRC, 2015). The FRC claims that the reports have been extremely helpful and informative for readers and the disclosures will greatly help increase the public confidence in the audit profession.

Another AQI framework was published in October 2015 by the Accounting and Corporate Regulatory Authority of Singapore (ACRA). Through its Practice Monitoring Program, the ACRA was able to identify key factors that led to poor quality audits. The main drivers of poor quality audits include inadequate time spent by managers and audit partners and a lack of dedicated resources. Based on its findings, ACRA set out to indicate what could define a quality audit. In collaboration with audit firms and audit committees, ACRA developed and published its voluntary AQI framework, which became available to audit committees in Singapore as of January 2016 (ACRA, 2015a).

The framework is broken down into the following eight different indicators that are communicated both at the engagement and the firm levels: 1) audit hours; 2) experience; 3) training; 4) inspection; 5) independence; 6) quality control; 7) staff oversight; and 8) attrition rate. The AQIs are designed to work collectively and they were chosen based on two principles: 1) the information should be presented as quantitative data so it can be easily compared by audit committees; and 2) the report should contain a mix of engagement level and firm level indicators. The engagement level indicators provide information that is more relevant to audit committees and firm level indicators help audit committees get an understanding of the audit firm's overall commitment to quality assurance measures 
(ACRA, 2015b). Following the release of the framework, ACRA published guidelines to help audit firms with preparation and to help audit committees with interpretation of AQI data (ACRA, 2016).

\section{CONCLUSIONS}

Reporting AQIs will improve the transparency of the audit process. Thus, it is likely that the AQI framework proposed by the PCAOB will be implemented in some form. The respondents to the PCAOB concept release generally support the AQI concept, and not adopting some version of the AQI framework would make the U.S. fall behind its global competitors. Worldwide, numerous firms already use an AQI framework on a voluntary basis, and building on their experiences is a good starting point. However, as many of respondents to the PCAOB recommended, there is still much work to be done. We agree that 28 indicators are too numerous, making the reporting and interpretation of AQIs overwhelming and confusing. The PCAOB either needs to create a tailored approach in which audit committees pick the audit quality indicators to suit their needs or condense the framework. The framework currently in place in the U.K. can be used as a template and the global accounting industry can help in moving toward a globalized set of AQI standards. Since accounting firms operate globally, a unified global framework for AQI reporting would be the most effective in making the audit process fully transparent and comparable.

\section{AUTHOR BIOGRAPHIES}

Arianna S. Pinello, Ph.D., CPA, CIA is an Associate Professor of Accounting in the Lutgert College of Business at Florida Gulf Coast University. She is a Certified Public Accountant, a Certified Internal Auditor, and a member of the American Accounting Association, the Institute of Internal Auditors, and the Florida Institute of Certified Public Accountants. Dr. Pinello earned her Ph.D. in Accounting from The Florida State University in 2004, and her research has been published in a variety of academic and professional accounting journals. E-mail: apinello@fgcu.edu

Ara G. Volkan, Ph.D., CPA joined the FGCU faculty in August 2004 as Eminent Scholar and Moorings Park Chair of Managerial Accounting. He served as the Chair of the Accounting Department and the Associate Dean and Interim Dean of the Lutgert College of Business during 2006-2014. He received his doctorate in accounting from The University of Alabama in 1979. Dr. Volkan is a member of the FICPA and AAA. He serves as reviewer for several journals. He published numerous articles in academic and professional accounting journals and in other outlets. Email: avolkan@fgcu.edu (contact author)

In collaboration with Florida Gulf Coast University M.S. in Accounting and Taxation Students:

Justin Franklin, MSAT is a senior accountant at Gartner, Inc. He received his masters degree in accounting and taxation from Florida Gulf Coast University in May 2018. E-mail: jafranklin@gmail.com

Michael Levatino, MSAT is a staff auditor at Myers, Brettholtz \& Co. He received his masters degree in accounting and taxation from Florida Gulf Coast University in May 2018. E-mail: michaeljlevatino@gmail.com

Kimberlee Tiernan, MSAT, CPA, CAM is the accounting manager for condominiums at Guest Services, Inc. She received her masters degree in accounting and taxation from Florida Gulf Coast University in May 2017. E-mail: tiernank@guestservices.com

\section{REFERENCES}

Accounting and Corporate Regulatory Authority (2015a). Guidance to Audit Firms on ACRA's Audit Quality Indicators Disclosure Framework. Singapore.

Accounting and Corporate Regulatory Authority (2015b). Guidance to Audit Committees on ACRA's Audit Quality Indicators Disclosure Framework. Singapore.

Accounting and Corporate Regulatory Authority (2016). Deepening the Audit Quality Conversion. Singapore.

Bedard, J. C., Johnstone, K. M., \& Smith, E. F. (2010). Audit Quality Indicators: A Status Update on Possible Public Disclosures and Insights from Audit Practice. Current Issues In Auditing, 4(1), C12-C19.

Center for Audit Quality (2014). CAQ Approach to Audit Quality Indicators. Washington, DC.

Choudhury, F. (2015). Concept Release on Audit Quality Indicators (AQI's) PCAOB Release No. 2015-005 [Letter to PCABO]. New York, New York.

DeFond, M., and J. Zhang (2014). A review of archival auditing research. Journal of Accounting and Economics 58(2), $275-326$. 
Federation of European Accountants (2015). Overview of Audit Quality Initiatives. Brussels, Belgium.

Financial Reporting Council (2006). Promoting Audit Quality. London, England.

Financial Reporting Council (2008). The Audit Quality Framework. London, England.

Financial Reporting Council (2015) Transparency Reporting by Auditors of Public Interest Entities. London, England.

Fornelli, C. (2016). Improving Audit Quality through Auditor Communication. CPA Journal, 86(2), 10-12.

Fuerman, R. (2015). PCAOB Release No. 2015-005 July 1, 2015; PCAOB Rulemaking Docket Matter No. 041 [Letter to PCAOB]. Suffolk University, Boston, MA.

Gaynor, L. M., Kelton, A. S., Mercer, M., \& Yohn, T. L. (2016). Understanding the Relation between Financial Reporting Quality and Audit Quality. Auditing: A Journal of Practice \& Theory, 35(4), 1-22.

Institute of Management Accountants (2015). PCAOB Rulemaking Docket Matter No. 041; Request for Comment: Concept Release on Audit Quality Indicators [Letter to PCAOB]. Washington, DC.

Jeffrey, G., (2016) Audit Tool Shows Promise in Eyes of Experts. The Bottom Line, 15-16.

Knechel, W. R., Krishnan, G. V., Pevzner, M., Shefchik, L. B., \& Velury, U. K. (2013). Audit Quality: Insights from the Academic Literature. Auditing: A Journal of Practice \& Theory, 32, 385-421.

PMG, LLP (2015). PCAOB Rulemaking Docket Matter No. 041; Request for Comment: Concept Release on Audit Quality Indicators [Letter to PCAOB]. New York, New York.

Martin, R. D. (2013). Audit Quality Indicators: Audit Practice Meets Audit Research. Current Issues in Auditing, 7(2), A17-A23.

Mahoney, Jeff (2015). Concept Release on Audit Quality Indicators (PCAOB Rulemaking Docket Matter No. 041) [Letter to PCAOB]. Council of Institutional Investors, Washington D.C.

McGladrey, LLP (2015). PCAOB Rulemaking Docket Matter No. 041 [Letter to PCAOB]. Chicago, IL.

Minnich, G. (2015). PCAOB Rulemaking Docket Matter No. 041 Concept Release on Audit Quality Indicators [Letter to PCAOB]. Belden, Inc, St. Louis, MO.

Public Company Accounting Oversight Board [PCAOB] (2015). PCAOB Release No. 2015-05 (PCAOB Rulemaking Docket Matter No. 041): Concept Release on Audit Quality Indicators. Washington, DC.

Rezaee, Z., Abernathy, J., Causholli, M., Michas, P. N., Roush, P. B., Rowe, S., \& Velury, U. K. (2016). Comments of the Auditing Standards Committee of the Auditing Section of the American Accounting Association on PCAOB Concept Release on Audit Quality Indicators, No. 2015-005, July 1, 2015. Current Issues in Auditing, 10(1), C11-C27.

Smith, E., Bedard, J. C., \& Johnstone, K. M. (2009). How Good is Your Audit Firm? NACD Directorship, 35(3), 64-67.

Tysiac, K. (2016). Audit Committees Prefer Customized, Tailored Audit Quality Indicators Journal of Accountancy, $221(3), 14$. 